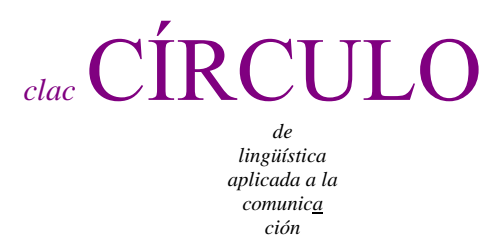

$57 / 2014$

PICTORIAL AND VERBO-PICTORIAL METAPHOR

IN SPANISH POLITICAL CARTOONING

Isabel Negro Alousque

inegro at ccee ucm es

Universidad Complutense de Madrid

\begin{abstract}
In the last forty years the development of the Cognitive Metaphor Theory (Lakoff 1987, 2006, Lakoff \& Johnson 1980) has given rise to a great amount of research into metaphor. The study of verbal metaphor was followed by several investigations into visual and multimodal metaphor (Forceville 2007, 2008, 2009). Whereas monomodal metaphor occurs in a single mode of representation, for instance verbal metaphor, pictorial metaphor or auditory metaphor, multimodal metaphor occurring in diverse modes, for instance verbo-pictorial metaphor. In much the same way, there have been numerous studies on metaphor-metonymy interaction cases in specialized genres. In the present article we explore monomodal visual and multimodal verbo-pictorial metaphors, and multimodal cases of metaphor-metonymy interaction (i.e. verbo-pictorial metonymy-based metaphors) in a corpus of Spanish print political cartoon strips drawn from the popular newspaper El País.
\end{abstract}

Key words: political cartoon, metaphor, metonymy, modality.

Negro Alousque, Isabel. 2014.

Pictorial and verbo-pictorial metaphor in Spanish political cartooning. Círculo de Lingüística Aplicada a la Comunicación 57, 59-84.

http://www.ucm.es/info/circulo/no57/negro.pdf

http://revistas.ucm.es/index.php/CLAC

DOI: http://dx.doi.org/10.5209/rev_CLAC.2014.v57.44515

(C)2014 Isabel Negro Alousque

Círculo de Lingüística Aplicada a la Comunicación (clac)

Universidad Complutense de Madrid. ISSN 1576-4737. http://www.ucm.es/info/circulo 
Contents

Abstract 59

1.1. Introduction 60

1.1. A cognitive approach to metaphor and metonymy 60

1.2. Multimodal metaphor 63

2. The genre of political cartooning 66

3. Data selection and analysis 67

4. Conclusion 78

References 79

1.1. Introduction

1.1. A cognitive approach to metaphor and metonymy

The structure of the paper is as follows. In this first section we shall consider the three basic theoretic components of this paper, i.e metaphor, metonymy and metaphormetonymy interaction cases from a cognitive perspective, and we will then focus on multimodal metaphor. This will be followed by a characterization of the genre of political cartooning. The third section offers a detailed description of fifteen Spanish print political cartoons from El País (Erlich and El Roto) profiling monomodal and multimodal metaphors in Spanish print political vignettes. Three issues will be addressed: a) how monomodal and multimodal metaphors are manifested in the corpus; b) how image and text interact in the corpus in a concrete type of multimodal metaphor, 
namely verbo-pictorial metaphor; c) how metaphor often conveys a strong axiological value supported by the 'only author's personalised' analysis of events. (Díez 2001).

In the last decades metaphor has been investigated within the cognitive linguistics framework. The Cognitive Metaphor Theory (CMT) developed by Lakoff and other scholars (e.g. Lakoff 1987, 2006; Lakoff \& Turner 1989; Lakoff \& Johnson 1980; Gibbs 1994; Gibbs, Bogdanovich et al., 1997; Kövecses 1990, 2000, 2002, 2005; Dirven \& Ruiz de Mendoza 2010; cf. Gibbs 2011, and Ruiz de Mendoza \& Pérez 2011 for assessment on the later versions) posits the ubiquity of metaphor in both everyday and specialized language and argues for a view of metaphor as a conceptual rather than linguistic device. As Gibbs (2008: 3) points out, «metaphor is not simply an ornamental aspect of language, but a fundamental scheme by which people conceptualize the world and their own action».

In a cognitive linguistics view, metaphor and metonymy occupy a central role in our conceptual structure. They are conceptual devices that contribute to providing structure to the human conceptual system ${ }^{1}$. They can be defined as conceptual mappings (i.e. sets of correspondences across distinct domains), which differ in the nature of the domain involved: in metaphor we find two different domains while in metonymy there is a domain-subdomain conceptual mapping.

Kövecses and Radden (1998) put forward a taxonomy of metonymic mappings relying upon a set of metonymy-producing relationships, i.e. generic principles underlying metonymies. Some metonymies are based on the part-whole organization of a domain, while others involve part-for-part relationships, i.e. one subdomain within a domain stands for another subdomain within the same domain. The latter are based on the formulation of several Idealized Cognitive Models (ICMs) ${ }^{2}$. For instance, in the

\footnotetext{
${ }^{1}$ Lakoff (1987) postulates four principles underlying conceptual structure: propositional structure, image schemas, metaphor and metonymy.

${ }^{2}$ An Idealized Cognitive Model can be defined as a cognitive structure used to represent reality from a certain perspective.
} 
perception ICM, There goes my knee (= the pain in my knee) is an example of the THING PERCEIVED FOR THE PERCEPTION, and a gorgeous sight of the PERCEPTION FOR THE THING PERCEIVED.

Ruiz de Mendoza and Otal (2002: 58) suggest two types of metonymy:

a) Source-in-target metonymies in which the source is a subdomain of the target, e.g. The flute feels sick today, where 'the flute' is a subdomain for 'the musician who plays the flute'. This kind of metonymy involves domain expansion.

b) Target-in-source metonymies in which the target is a subdomain of the source, for example the metonymies based on Kövecses and Radden's part-for-part relationship and those based on other frames like the product and the location frames, e.g. The Velázquez is in the hall, where by 'Velázquez' we refer to 'one of his paintings' which is a subdomain of our knowledge about this painter. Target-in-source metonymies involve domain reduction and the consequent highlighting of part of a domain.

Metonymies and (less frequently) metaphors also occur within metaphoric and metonymic complexes (Ruiz de Mendoza \& Mairal 2007: 77), i.e. double metonymies and double metaphors. Ruiz de Mendoza and Díez (2002) examine the patterns that arise when two metonymies work in combination. Since metonymy is based on domaininclusion relationships where the source may be a subdomain of the target or the target a subdomain of the source, metonymy consists of domain expansion and reduction operations. Four double metonymy types can be distinguished:

1. Double domain reduction, as in Wall Street is in panic. This pattern, illustrated by the double metonymy PLACE FOR INSTITUTION FOR PEOPLE (RELATED TO THE INSTITUTION), involves two subsequent reductions of the source domain

2. Double domain expansion, as in His sister heads the policy unit. This type of mapping involves two subsequent expansions of the source domain.

3. Domain reduction and domain expansion, as in Proust is on the top shelf. This pattern combines a target-in-source and a source-in-target metonymies. 
4. Domain expansion and domain reduction, as in He has too much lip. This type of mapping combines a source-in-target and a target-in-source metonymy.

Metaphor and metonymy often interplay. Some authors (Ruiz de Mendoza 1999a, 2000; Radden 2000; Barcelona 2000; Ruiz de Mendoza \& Otal 2002; Ruiz de Mendoza \& Díez 2002; Panther, Thornburg \& Barcelona 2006; Benczes, Barcelona \& Ruiz de Mendoza 2011; Gonzálvez-García, Peña \& Pérez 2011) have examined the conceptual interaction between metaphor and metonymy. Thus, Goossens (1990) postulates four ways in which metaphor and metonymy interact: (1) metaphor from metonymy, i.e. a metaphor is grounded in a metonymic mapping; (2) metonymy within metaphor; (3) demetonymization inside a metaphor; and (4) metaphor within metonymy. We follow Ruiz de Mendoza and Otal's (2002) view that because of its nature metaphor is subsidiary in conceptual interaction to metonymy. Therefore, it is not possible to include the two domains of metaphor within the single domain of metonymy. In the light of this, Ruiz de Mendoza and Mairal (2007: 77), argue for the existence of conceptual chains where a metonymy is subsumed within a metaphor, thus triggering a metonymy-based metaphor. It must be noted that Ruiz de Mendoza's approach to metaphor and metonymy has helped us to provide a clearer picture of the multimodal metaphors and metonymies found in our corpus.

\subsection{Multimodal metaphor}

Although the bulk of research has hitherto focused on verbal metaphor, an increasing number of recent investigations have been concerned with other types of metaphor. Visual (or pictorial) metaphor and multimodal metaphor are the most examined types of non-verbal metaphor. Forceville (2009: 24) defines multimodal metaphors in the following terms: «[...] metaphors whose target and source are rendered in two different modes/modalities [...] and in many cases the verbal is one of these». Koller (2009: 46) claims that «multimodal metaphor is constituted by a mapping, or blending, of domains from different modes». 
Forceville (2009: 21) postulates the following modes in the investigation of multimodal metaphor:

- pictorial signs

- written signs

- $\quad$ spoken signs

- gestures

- sounds

- music

- smells

- tastes

- touch

Although visual and multimodal metaphors share many of the features of verbal metaphors, they differ from them in several ways (Forceville 2008: 463, 476):

1. They have a high degree of specificity resulting from their perceptual immediacy.

2. They are more easily recognized across languages and cultures, since they do not rely on language codes.

3. They have medium-determined ways of cueing the similarity between target and source.

4. They have a stronger emotional impact.

Whereas some scholars give a theoretical account of pictorial (e.g. Forceville 1994, 1996) and multimodal (e.g. Kress \& Van Leeuwen 2001, 2006 (1996); Ventola, Cassily \& Kaltenbacher 2004; Baldry \& Thibault 2006; Forceville 2008, 2009) metaphor, others have studied the use of these metaphor types in specialized language (Forceville 2008, Cienki \& Müller 2008; Zbikowski 2008; Ventola \& Guijarro 2009), including winespeak (Amoraritei 2002; Caballero 2009; Caballero \& Suárez-Toste 2008, 2010), advertising (Messaris 1997; Philips 2003; Wiggin \& Miller 2003, Velasco-Sacristán \& Fuertes-Olivera 2004, 2006a,b; Forceville 1996, 2007, 2008, 2009; Koller 2009; McQuarrie \& Philips 2008; Caballero 2009; Ning Yu 2009; Urios-Aparisi 2009), film (Forceville 2005; Rohdin 2009; Eggerstsson \& Forceville 2009), oral speech 
accompanied by gestures (Cienki 1998; McNeill 1992, 2005; Cienki \& Müller 2009); comics, manga and animation (Eerden 2009; Shinohara \& Matsunaka 2009), and music and sound (Zbikowski 2009; Forceville 2009). The political cartoon is another genre that is currently being discussed by metaphor scholars (Forceville 2005; El Refaie 2003, 2009; Schilperoord \& Maes 2009; Teng 2009; Yus 2009).

Of all types of multimodal metaphor, multimodal metaphor of the verbo-pictorial variety (Forceville 1996, 2009) has attracted much scholarly attention. Forceville's notion of verbo-pictorial metaphor considers the modes in which a conceptual metaphor is manifested and the representation of the source and the target domains. In his first book (1996), Forceville defines a verbo-pictorial metaphor as a metaphor whose source is visually represented and the target is verbally represented or viceversa; in a subsequent study (2009), a verbo-pictorial metaphor is a metaphor always encoded visually and occasionally in an additional verbal form. Such definition of multimodal metaphor should be extended to embrace the following typical features of multimodal metaphor in political cartoons:

a) Both the source and the target are visually and verbally cued.

b) The source is rendered visually and verbally and the target is rendered visually.

c) The source is visually and verbally cued and the target is rendered verbally.

d) The source is verbally rendered and the target is visually and verbally cued.

e) The source is represented via language and the target is represented via image.

f) The source is pictorially represented and the target is verbally represented.

Within the cognitive framework and taking multimodal studies into consideration, we intend to develop corpus-based research in the field of Spanish print political cartoons, a field which, to the best of our knowledge, has not been explored yet. Thus, the present contribution may be regarded as a continuation and integration of previous research into specialized language, more specifically, political cartooning. 
2. The genre of political cartooning

El Refaie (2009: 175) suggests the following definition of a cartoon:

A cartoon is an illustration, usually in a single panel, published in the editorial or comments pages of a newspaper. Generally, the purpose of a political cartoon is to represent an aspect of social, cultural or political life in a way that condenses reality and transforms it in a striking, original and/or humorous way.

The defining features of political cartoons may be summarized as follows:

1. They have a descriptive function inasmuch as they are characterized by allusion to a socio-political situation, event or person.

2. Since they are related to recent events, factual knowledge is essential for their correct interpretation.

3. Recent events are combined with an imaginary world in such a way that «cartoons act as a bridge between fact and fiction» (Edwards 1997: 8). The metaphorical process of transferring meaning from the imaginary to the real world is conveyed predominantly in the visual mode (El Refaie 2009: 174).

4. Cartoons have a satirical nature. They are characterized by caricature, which parodies the individual.

5. The last feature stems from the previous one: Cartoons exemplify critical perspectives on recent events.

6. Metaphor is a recurrent device used in political cartooning (Edwards 1997; Philippe 1982; Templin 1999). As Shilperoord and Maes (2009: 214-215) remark, «editorial cartoons are a metaphor-rich communicative area». In this light, these authors highlight the scenario character of newspaper cartoon metaphors, the most frequent scenarios being the hospital-scenario, the cooking-scenario, marriage, funerals and (boxing) games. 


\section{Data selection and analysis}

To illustrate the use of metaphor and metonymy in political cartooning, ten Spanish print cartoons have been selected. The instances presented here have been drawn by two well-known cartoonists, Erlich and El Roto, and were published in the widely read newspaper El País mostly in 2011. The cartoons instantiate monomodal visual and multimodal verbo-pictorial metaphors. Anthropomorphic metaphors are exploited in several vignettes (see below). This confirms Forceville and Urios-Aparisi's claim (2009: 13) that personification is an essential variety of multimodal metaphor. Our study also shows that the role of spatial dimensions in source domains is more noticeable in visual discourses than in verbal ones (Forceville \& Urios-Aparisi 2009: 13).

A considerable number of metaphors encountered in the sample are metonymy-based. The metonymies are largely represented though the visual mode, thus involving a mapping within a single domain from the source image to the target one.

This study of Spanish cartoons addresses the following issues: (i) description of the image shown in the cartoon; (ii) analysis of the metaphors and metonymies in terms of the target and source domains; the visual and/or verbal representation of those domains, (iii) the interaction between metaphor and metonymy and (iv) their axiological value.

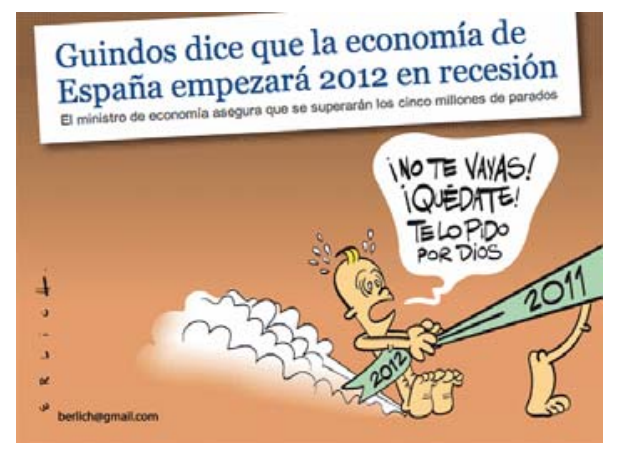

Figure 1. Erlich (El País, 27 December 2011). 
The cartoon in figure 1 evokes the Spanish recession in 2012. The target is conveyed by a reference to the years 2011 and 2012 in the picture and a newspaper headline and lead concerning the statement made by the Spanish Ministry of Finance about the economy in the early months of 2012. The vignette profiles a conceptual chain. The central metaphors are THE ECONOMY IS A PERSON and THE ECONOMY IS TIME PASSING. These metaphors are visually cued. Our economy is depicted as a child pulling after his father's sash (i.e. the economic recession in 2011) and begging him not to go: ¡No te vayas! ¡Quédate! 'Don’t leave! Stay!'. The sash can be interpreted as a visual representation of the source in the metaphor TIME PASSING IS MOTION OF A SASH, which is subsumed within the ECONOMY IS TIME PASSING metaphor. Such conceptual chain is illustrated in figure 2:

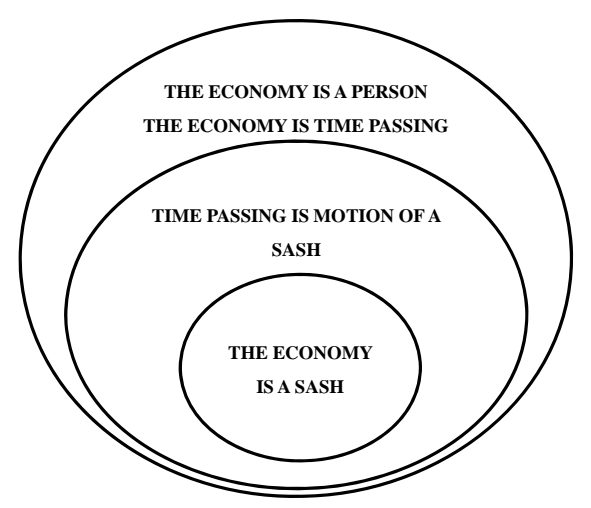

Figure 2. Conceptual chain.

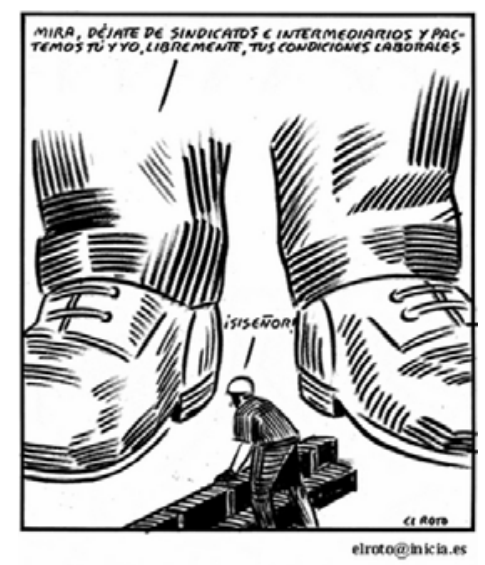


Figure 3. El Roto (El País, 28 January 2012).

The second cartoon (figure 3) is a good example of how size can be imbued with metonymic-based metaphoric meaning. The image depicts industrial relations. We see two human figures, a building contractor and a bricklayer, both metonymically standing for the category, thus profiling the metonymy PERSON FOR PEOPLE. At the same time the employer is represented by two enormous feet. Thus there are two part-for-thewhole metonymies which are linked in such a way that the target domain of the first metonymy works as the source of the second metonymy: FEET FOR PERSON FOR PEOPLE (EMPLOYERS). Hence, this is an instance of double domain expansion, as illustrated in figure 4:

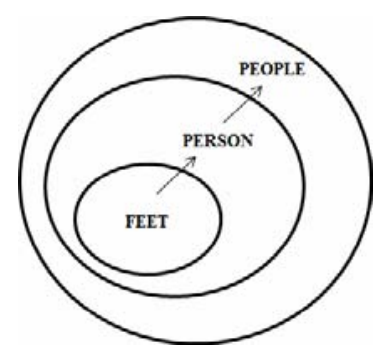

Figure 4. FEET FOR PERSON FOR PEOPLE metonymy.

The size of the man's feet and his upright position yield two interrelated metaphors: the conceptual metaphor BIG IS POWERFUL and the orientational metaphor POWER IS UP. In much the same way, the small size of the other human figure suggests the metaphorical reading that SMALL IS WEAK. This interpretation is corroborated by the worker's answer to the building contractor's suggestion: ¡Sí señor! These words are uttered by soldiers in response to their officers' orders and denote an attitude of obedience and submissiveness. The employer's sentence - 'Forget about unions and mediators and let us negotiate your working conditions' are inconsistent with the image, thus leading to an unfavourable attitude toward employers' views. In addition, the employer is seemingly going to stamp on the bricklayer. This detail triggers the visual metaphor WORK IS A WALK, the walk being carried out by the employer on the bricklayer. Again this is a metaphor based on spatial dimensions: EMPLOYERS (THE BUILDING CONTRACTORS) ARE OVER EMPLOYEES, which is grounded on the up-down and part-whole metonymies. 


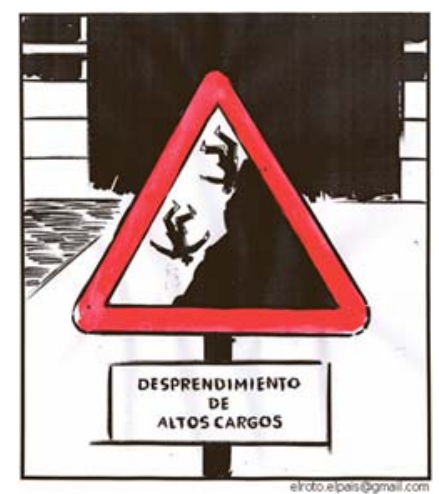

Figure 5. El Roto (El País, 28 November 2011).

The metaphor POWER IS UP also motivates the cartoon shown in figure 5. The cartoon, which refers to government officials' loss of position, is another clear instance of a metaphorical chain. The image of two falling men and the verbal element of the traffic sign (altos cargos) point to the high-low scale basis of the metaphor. The metaphor is thus based on a metonymy. Power is represented verbally by the altos cargos and the bajos cargos (workers) are represented visually. The illustration reflects another metonymy-based metaphor, WORK IS ROCK, in which the ROCKS ARE PEOPLE, more specifically altos cargos. This metaphor is subsumed within the POWER IS UP metaphor (figure 6).

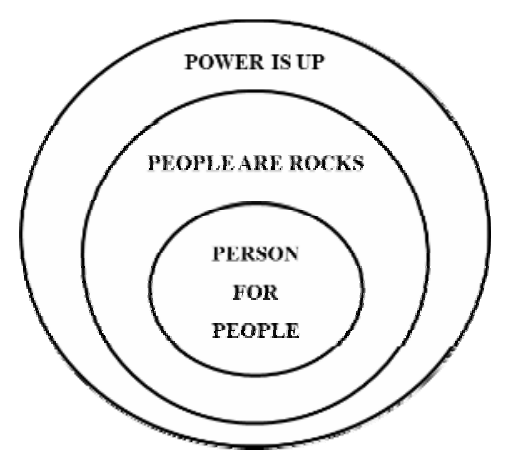

Figure 6. Conceptual chain.

It must be noted in passing that such conceptual complex is integrated into the metaphorical frame of road transport inasmuch as the image is placed in a rockfall warning road sign. 


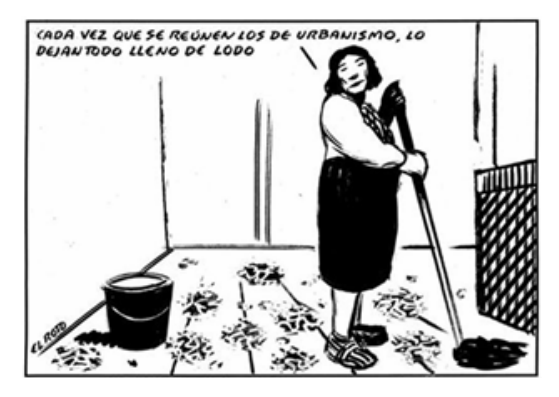

Figure 7. El Roto (El País, July 2007)

A similar verbo-pictorial metonymy-based metaphor is to be construed in the cartoon shown in figure 7 . We see the picture of a cleaning lady mopping the floor. A closer look at the text and the illustration reveals that they are meant to metaphorically represent political corruption. El Roto questions the fair practices of the Town Planning Commission. The target is rendered by the expression los de urbanismo 'the members of the Town Planning Commission'. The source object, mud, is represented verbally the word lodo in the accompanying text, and pictorially - the image of the mud footprints left by the members of the commission on the floor. The connection between the verbal and the visual component is obtained via the metonymy FOOTSPRINT FOR PERSON, which is subsumed within the metaphor CORRUPTION IS DIRT. What we have here is the incorporation of a subsidiary metonymy into the architecture of the metaphor. It is important to mention that the metaphor is sustained in a gender stereotype about male and female jobs, since it is a woman who cleans the dirt (corruption). Nevertheless, this sexist interpretation is counterbalanced by the fact that the cleaning woman leaves her footsprints behind, which conveys the message that there are also corrupted women.

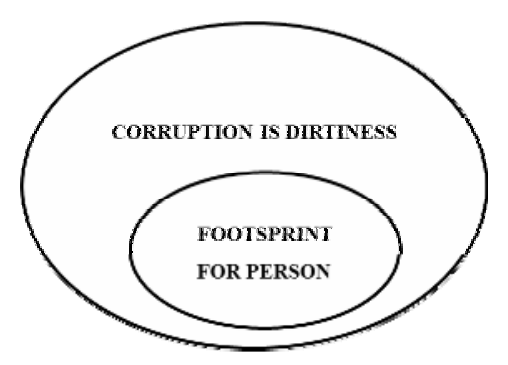

Figure 8. Metonymy subsumption within metaphor. 


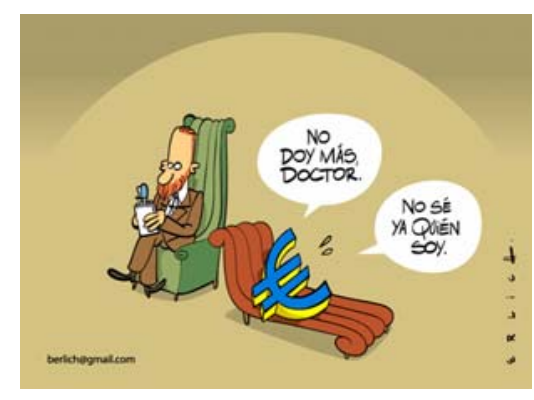

Figure 9. Erlich (El País, 1 October 2011).

The cartoon in figure 9 depicts the euro crisis. Again two metonymy-based metaphors based on embodiment are manifested here: CURRENCY (the euro) IS A SICK PERSON whereas PSYCHOANALYSTS ARE POLITICIANS looking after sick currencies like the euro. The former is subsumed within a part-whole metonymy, the euro standing for the European Union. The cartoonist's negative viewpoint of the crisis is made explicit in the words uttered by the sick person: No doy más, doctor; No sé ya quién soy 'I can't cope with more, doctor; I no longer know who I am'. These metaphors are subsumed within the metaphor THE ECONOMY IS A PATIENT, proposed by Charteris-Black (2000a: 156) and later developed by Richardt (2003: 277). Recent research has shown the ubiquity of organismic metaphors in economic thought and discourse (White, 2003: 134-143). A set of organismic metaphors, LIFE-BODYHEALTH metaphors, demonstrate the prominence of HEALTH and ILLESS concepts in business press language. Economic problems are often conceptualized as diseases that weaken the economy and threaten its health schema. The economy is the patient who receives medical treatment from economists. The cartoon under study activates this medical frame with the following mappings:

1. An economic analyst is a psychoanalyst who treats the sick euro.

2. The euro is the patient who needs to undergo medical treatment to recover. 


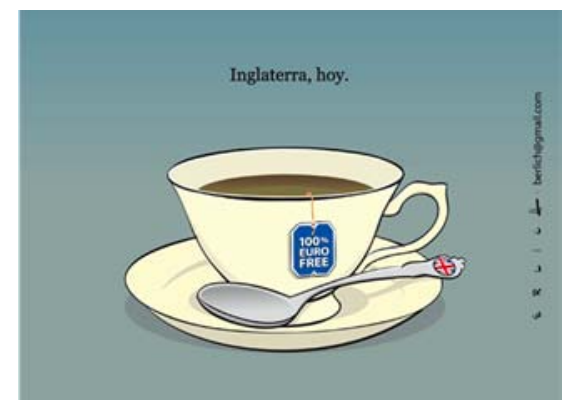

Figure 10. Erlich (El País, 10 December 2011).

The image of the next cartoon (figure 10) is cognitively rich. The image triggers the metaphor ENGLAND IS TEA, based on two part-whole metonymies, PART OF A COUNTRY FOR THE WHOLE COUNTRY (Inglaterra 'England' standing for the whole Great Britain) and THING (RELATED TO A COUNTRY) FOR COUNTRY, the tea being the British national drink. In addition, the metaphorical expression ' $100 \%$ EURO FREE' is the verbal instantiation of a further metonymy-based metaphor EUROPE IS CAFFEINE (Euro non-free), where the target is metonymically represented by the euro. The metaphor suggests the positive value of the fact that tea does not have caffeine.

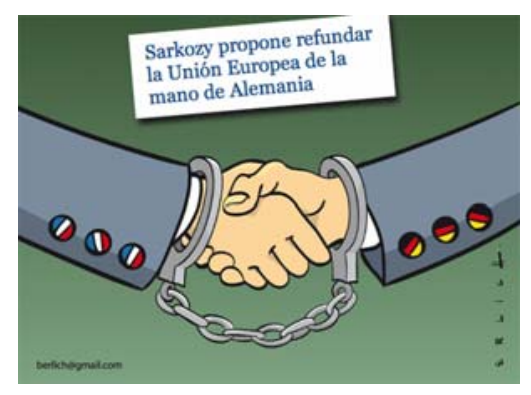

Figure 11. Erlich (El País, 2 December 2011).

The issue of freedom is at stake in the cartoon shown in figure 11, which illustrates the role of the verbal message in the identification of the source and the target of the metonymy that can be derived from the image. The text, a newspaper headline, refers to Sarkozy's (the former French president) intention to restructure The European Union under Germany's leadership, Germany standing metonymically for the German chancellor (A COUNTRY FOR ITS RULERS). The illustration shows two shaking 
hands. The connection with the image is established by means of a pictorial detail and a verbal cue. The former is the design of the jacket buttons shown in the picture - they are in the colours of the German and French flags, respectively. The latter is the idiom in the headline, de la mano de Alemania. It is striking that the image triggers off the literal meaning of the nuclear constituent mano 'hand' in the idiom ${ }^{3}$ and encodes a part for whole metonymy, since the hands are seemingly Sarkozy's and Merkel's.

It is worth mentioning that Sarkozy and Merkel are handcuffed. This detail encodes the metonymy-based metaphor RULERS ARE HANDCUFFED (i.e. 'lacked of freedom') suggesting that RULERS ARE PRISONERS. The hands that they are shaking reflect the metonymy-based metaphor SHAKING HANDS IS MAKING A DEAL. This expresses the cartoonist's critical instance toward the French-German deal, suggesting France's heavy dependence on Germany.

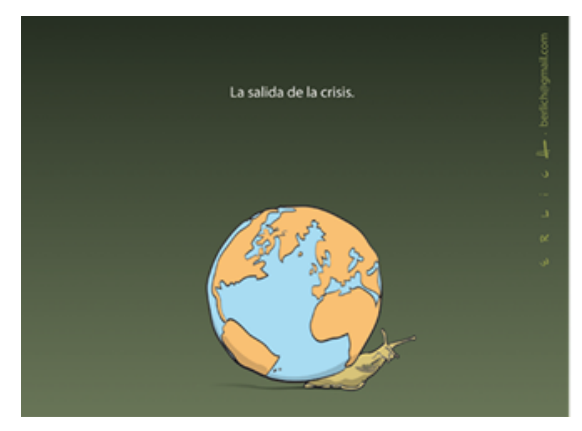

Figure 12. Erlich (El País, 30 October 2011).

The image-text integration is noticeable in the cartoon shown in figure 12, directing the reader to the right interpretation of the verbal content. The image illustrates a hybrid metaphor (Forceville 1996: 163) where the target and the source are fused into a

\footnotetext{
${ }^{3}$ This is a case of idiomatic semantic variation (i.e. variation in meaning through ambiguation (Langlotz 1996), that is, by giving the expression a literal reading.
} 
semantically bounded object. The cartoon features the solution to the global financial crisis and uses simultaneously a visual - the earth globe and a verbal element - the phrase La salida de la crisis 'the way out of the crisis' to represent the target of the metaphor. Additionally, it must be noted that the word salida and the feature mapped by the image - SLOW MOVEMENT manifest the general metaphor EVENTS ARE MOVEMENTS. The target object of the earth globe as a conventional representation of the world and the source object of the snail are fused in such a way that the globe works as the shell of the snail. Such fused image profiles the metaphor THE ECONOMY IS AN ANIMAL who is overloaded by the world that stands for the crisis (THE WORLD IS THE CRISIS). Again this is a part for whole metonymy-based metaphor, the snail standing for all countries. It is worth pointing out the axiological value of the weight of the globe on the animal, which may prevent it from getting away from the world crisis and even kill it. The source domain of animals allows for the mapping of idiosyncratic features (Forceville \& Urios-Aparisi 2009: 13). In line with this, the metaphoric mapping relies on the feature of SLOW MOVEMENT, thus yielding the interpretation that world countries will come out of the recession slowly.

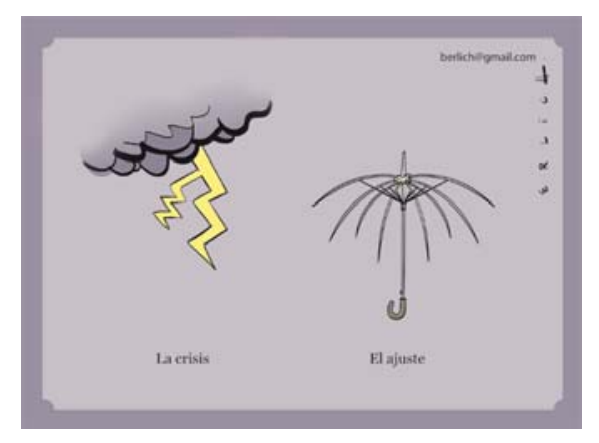

Figure 13. Erlich (El País, 12 October 2011).

The topic of the following cartoon (see figure 13) is also the global crisis. The image of a flash of lightning and an umbrella can be interpreted as a visual representation of the source in the metaphor CRISIS IS A STORM. The target is explicitly referred to in the phrases La crisis y El ajuste 'Adjustment'. The complementary image of the umbrella without ribs is a pictorial antonym for protection against rains like economic crises. Two visual details have an important communicative effect: the size of the umbrella, 
which is too small for the huge economic crisis over it, and the fact that the storm is not over the umbrella. These details reveal the cartoonist's doubts about the efficiency of the austerity measures taken by governments.

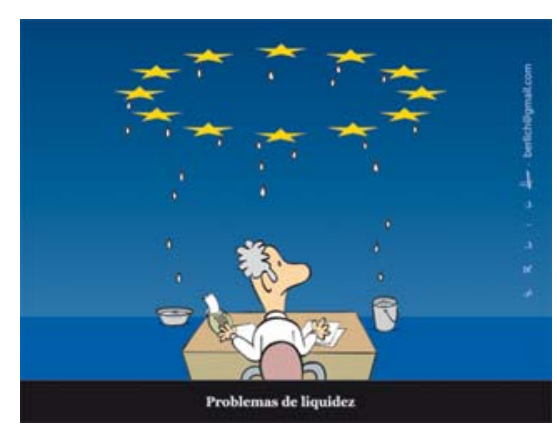

Figure 14. Erlich (El País, 5 January 2012).

Then cartoon shown in figure 14 reflects the metaphors THE EUROPEAN UNION IS A CLOUD THAT IS RAINING and WATER IS CRISIS. The European Union is metonymically represented by its flag. Curiously, the water source is anchored by the caption Problemas de liquidez 'Liquidity problems', where the word liquidez verbalizes the metaphor MONEY IS WATER. The man sitting at a desk and collecting the water (money) in small containers stands metonymically for the European rulers who are in great need of financial help from the European Union. Size is again relevant: the pail and bucket are too small for the protection needed under the wet euro.

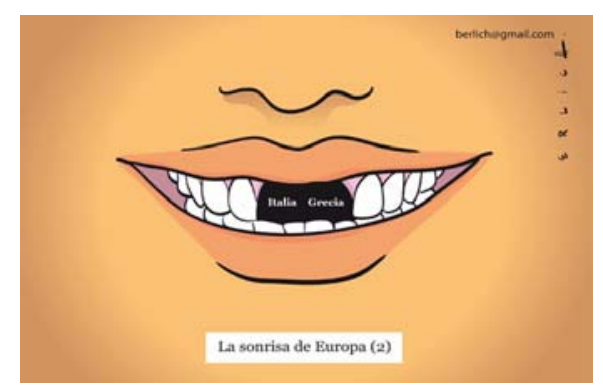

Figure 15. Erlich (El País, 13 November 2011). 
The next cartoon (figure 15) renders a human view of the European Union through visual and verbal signs - the caption La sonrisa de Europa 'Europe's smile'. We see the mouth of a smiling woman metonymically representing the European Union with two missing teeth, the names of two EU countries - Italy and Greece being written on them. The meaning of the cartoon is built upon the metaphor ORGANIZATIONS ARE PEOPLE and the part-whole metonymy MOUTH FOR PERSON subsumed within the metaphor. It is important to draw attention to the fact that the missing teeth give rise to a subsidiary metaphor, TOOTH DECAY IS COUNTRIES WITH SERIOUS CRISIS, like Italy and Greece.

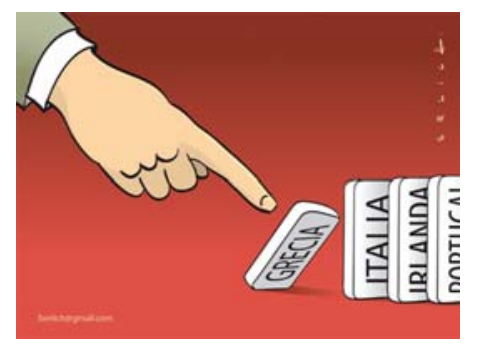

Figure 16. Erlich (El País, 8 November 2011).

Another conceptualization of the situation of a few countries in the Eurozone is supplied by the cartoon in figure 16, which relies on the game scenario. Games often work as source domains in political cartooning (Shiperoord \& Maes 2009: 227). The metaphor that is instantiated from the image and the words is THE GLOBAL FINANCIAL CRISIS IS A DOMINO GAME. This metaphor has an up-down basis and relies on a metonymy inasmuch as there are only four pieces of the domino that stand for specific European countries as indicated verbally on them - Greece already falling and about to pull down Italy, which will pull down Ireland and so on. The choice of this game as the source is justified on the basis of the domino effect, which is used to express metaphorically a cause-effect relationship within the global financial system, thus meaning that the debt crisis affecting a European country will affect other countries. Furthermore, the crisis is pictorially cued as a finger, again a part for whole personification metaphor of the world crisis. 


\section{Conclusion}

The present article has attempted to develop research into visual monomodal and verbopictorial multimodal metaphor in the genre of political cartooning. In monomodal metaphor, both target and source are represented in the same mode, whereas in multimodal metaphor they are represented in at least two different modes.

The corpus-based analysis suggests the frequent use of metaphor and metonymy in Spanish print political cartoon strips and highlights the following facts:

(a) Metonymy is found to be very productive to metaphoric activity. In this light, a considerable proportion of metaphors are based on a metonymy.

(b) Of the two types of metonymy put forward by Ruiz de Mendoza and Otal (2002), the source-in-target type is predominant in our corpus. More specifically, part for whole metonymy seems to provide the basis for numerous metaphors.

(c) Interestingly, metaphor and metonymy often occur in a conceptual chain where a metonymy is subsumed within a metaphor or a metaphor is integrated into another metaphor.

(d) The image-text integration makes it possible to construe the metaphors (and metonymies) underpinning the political cartoons, inasmuch as the source and target are not always encoded in both the written and visual modes. As a matter of fact, the target and source of the metaphors are represented primarily in visual and verbal terms, whereas metonymies are encoded visually.

(e) Metaphor frequently carries a strong axiological value, thus revealing the cartoonist's negative take on the news event depicted in the cartoon strip.

Further research needs to address this issue in a more systematic way. The scope of this contribution being limited, it seems that a deeper analysis of multimodal metaphor in specialized genres using larger corpora should be done. 


\section{References}

Baldry, Anthony \& Thibault, Paul (2006). Multimodal Transcription and Text Analysis: A Multimedia Toolkit and Coursebook. London: Equinox.

Barcelona, Antonio (2000) (ed.). Metaphor and Metonymy at the Crossroads. Berlin/ New York: Mouton de Gruyter.

Barcelona, Antonio (2005): The multilevel operation of metonymy in grammar and discourse with particular attention to metonymic chains. In F.J. Ruiz de Mendoza \& S. Peña (eds.), Cognitive Linguistics. Internal Dynamics and Interdisciplinary Interaction, 313-352. Berlin/ New York: Mouton de Gruyter.

Benczes, Réka; Barcelona, Antonio \& Ruiz de Mendoza, Francisco J. (eds.) (2011). Defining Metonymy in Cognitive Linguistics: Towards a Consensus View. Amsterdam \& Philadelphia: John Benjamins.

Caballero, Rosario (2009): Cutting across the senses: Imagery in winespeak and audiovisual promotion. In C. Forceville \& E. Urios-Aparisi (eds.), 73-94.

Caballero, Rosario \& Suárez-Toste, Ernesto (2008): Translating the senses. Teaching the metaphors in winespeak. In F. Boers \& S. Lindstromberg (eds.), Cognitive Linguistic Approaches to Teaching Vocabulary and Phraseology, 241-259. Berlin/New York: Mouton de Gruyter.

Caballero, Rosario \& Suárez-Toste, Ernesto (2010): A genre approach to imagery in winespeak: Issues and prospects". In G. Low et al. (eds.), Researching and Applying Metaphor in the Real World, 265-288. Amsterdam/Philadelphia: John Benjamins.

Carroll, Noel (1994): Visual metaphor. In J. Hintikka (ed.), Aspects of Metaphor, 189218. Dordrecht: Kluwer.

Charteris-Black, Jonathan (2000): Metaphor and Vocabulary Teaching in ESP Economics. ESP Journal 19: 149-165.

Cienki, Alan (1998): Metaphoric gestures and some of their relations to verbal metaphorical expressions. In J.P. Koenig (ed.), Discourse and Cognition: Bridging 
the Gap, 189-204. Stanford, CA: Center for the Study of Language and Information.

Cienki, Alan \& Müller, Cornelia (eds.) (2008). Metaphor and Gesture. Amsterdam/ Philadelphia: Benjamins.

Dirven, René \& Ruiz de Mendoza, Francisco J. (2010): Looking back at 30 years of Cognitive Linguistics. In E. Tabakowska, M. Choiński \& L. Wiraszka (eds.), Cognitive Linguistics in Action: from Theory to Application and Back, 13-70. Berlin/Nueva York: Mouton de Gruyter.

Eerden, Bart (2009): Anger in Asterix: The metaphorical representation of anger in comics and animated films. In C. Forceville \& E. Urios-Aparisi (eds), 243-264.

Eggerstsson, Gunnar \& Forceville, Charles (2009): Multimodal expressions of the human victim is an animal metaphor in horror films. In C. Forceville \& E. UriosAparisi (eds.), 429-49.

El Refaie, Elisabeth (2003): Understanding visual metaphor: the example of newspaper cartoons". Visual Communication 2(1): 75-95.

El Refaie, Elisabeth (2009): Metaphor in political cartoons: Exploring audience responses. In C. Forceville \& E. Urios-Aparisi (eds.), 19-42.

Forceville, Charles (1994): Pictorial metaphor in advertisements. Metaphor and Symbolic Activity 9: 1-29.

Forceville, Charles (1996). Pictorial Metaphor in Advertising. London: Routledge.

Forceville, Charles (2005): Addressing an audience: time, place, and genre in Peter Van Straaten's calendar cartoons. Humor: International Journal of Humor Research 18: 247-278.

Forceville, Charles (2007): Multimodal metaphor in ten Dutch TV commercials. Public Journal of Semiotics 1(1): 19-51.

Forceville, Charles (2008): Metaphors in pictures and multimodal representations. In R. W. Jr. Gibbs (ed.), The Cambridge Handbook of Metaphor and Thought, 462-482. Cambridge: Cambridge University Press. 
Forceville, Charles (2009): Non-verbal and multimodal metaphor in a cognitivist framework: Agendas for research. In C. Forceville \& E. Urios-Aparisi (eds.), 19-42.

Gibbs, Raymond W. Jr. (1994). The Poetics of Mind: Figurative Thought, Language, and Understanding. Cambridge: Cambridge University Press.

Gibbs, Raymond W. Jr.; Bogdanovich, Josephine M.; Sykes, Jeffrey R. \& Barr, Dale J. (1997): Metaphor in idiom comprehension. Journal of Memory and Language 37: 141-154.

Gonzálvez-García, Francisco; Peña, Sandra \& Pérez, Lorena (eds.) (2011): Metaphor and metonymy revisited beyond the Contemporary Theory of Metaphor. Recent developments and applications. Review of Cognitive Linguistics 9:1.

Goossens, Louis (1990): Metaphtonymy: the interaction of metaphor and metonymy in expressions for linguistic action. Cognitive Linguistics 1-3: 323-340.

Johnson, Mark (1987). The Body in the Mind: The Bodily Basis of Meaning, Imagination and Reason. Chicago: University of Chicago Press.

Koller, Veronika (2009): Brand images: Multimodal metaphor in corporate branding messages. In C. Forceville \& E. Urios-Aparisi (eds.), 45-71.

Kövecses, Zoltan (1990). Emotion Concepts. New York: Springer.

Kövecses, Zoltan (2000). Metaphor and Emotion. Language, Culture and Body in Human Feeling. Cambridge: Cambridge University Press.

Kövecses, Zoltan (2002). Metaphor: A Practical Introduction. Oxford: Oxford University Press.

Kövecses, Zoltan (2005). Metaphor in Culture: Universality and Variation. Cambridge: Cambridge University Press.

Kövecses, Zoltan \& Radden, Günter (1998): Metonymy: developing a cognitive linguistic view. Cognitive Linguistics 9 (1): 37-77.

Kress, Gunther \& van Leeuwen, Theo (2001). Multimodal discourse: The Modes and Media of Contemporary Communication. London: Arnold.

Lakoff, George (1987). Women, Fire and Dangerous Things: What Categories Reveal about the Mind. Chicago: University of Chicago Press. 
Lakoff, George (2006): The contemporary theory of metaphor. In D. Geeraerts (ed.), Cognitive Linguistics: Basic Readings, 186-238. Berlin/New York: Mouton de Gruyter.

Lakoff, George \& Johnson, Mark (1980). Metaphors We Live By. Chicago: Chicago University Press.

Lakoff, George \& Turner, Mark (1989). More than Cool Reason: A Field Guide to Poetic Metaphor. Chicago: University of Chicago Press.

Langlotz, Andreas (2006). Idiomatic Creativity. Amsterdam: John Benjamins.

McNeill, David (1992). Hand and Mind: What Gestures Reveal about Thought. Chicago: University of Chicago Press.

McNeill, David (2005). Gesture and Thought. Chicago: University of Chicago Press.

Messaris, Paul (1997). Visual Persuasion: The Role of Images in Advertising. California: Sage Publications.

Niemeier, Susanne (2000): Straight from the heart - metonymic and metaphorical explorations. In A. Barcelona (ed.), 195-214.

Panther, Klaus-Uwe; Thornburg, Linda \& Barcelona, Antonio (2009). Metaphor and Metonymy in Grammar. Amsterdam/Philadelphia: John Benjamins.

Philippe, Robert (1982). Political Graphics: Art as Weapon. Oxford: Phaidon Press.

Phillips, Barbara J. (2003): Understanding visual metaphor in advertising. In L.M. Scott \& R. Batra (eds.), 297-310.

Radden, Günter (2000): How metonymic are metaphors? In A. Barcelona (ed.), 93-108.

Richardt, Susanne (2003): Metaphors in expert and common-sense reasoning. In C. ZelinskyWibbelt (ed.), Text, Context, Concepts, 243-296. Berlin/New York: Mouton de Gruyter.

Rohdin, Maths (2009): Multimodal metaphor in classical film theory from the 1920s to the 1850s'. In C. Forceville \& E. Urios-Aparasi (eds.), 403-428.

Ruiz de Mendoza, Francisco J. (1999a). Introducción a la Teoría Cognitiva de la Metonimia. Granada: Método Ediciones.

Ruiz de Mendoza, Francisco J. (2000): The role of mappings and domains in understanding metonymy. In A. Barcelona (ed.), 109-132. 
Ruiz de Mendoza, Francisco J. \& Díez Velasco, Olga (2002): Patterns of conceptual interaction. In R. Dirven \& R. Pörings (eds.), Metaphor and Metonymy in Comparison and Contrast, 489-532. Berlin/ New York: Mouton de Gruyter.

Ruiz de Mendoza Ibáñez, Francisco J. \& Díez Velasco, Olga (2003): High-level metonymy and linguistic structure. In C. Inchaurralde \& C. Florén, C. (eds.), Interaction and Cognition in Linguistics, 189-210. Frankfurt and New York: Peter Lang.

Ruiz de Mendoza, Francisco J. \& Mairal, Ricardo (2007): High-level metaphor and metonymy in meaning construction. In G. Radden, K.-M. Köpcke, T. Berg et al. (eds.), Aspects of Meaning Construction, 33-51. Amsterdam/Philadelphia: John Benjamins.

Ruiz de Mendoza, Francisco J. \& Otal, José Luis (2002). Metonymy, Grammar and Communication. Granada: Comares.

Schilperoord, Joost \& Maes, Alfonso (2009): Visual metaphoric conceptualization in editorial cartoons. In C. Forceville \& E. Urios-Aparasi (eds.), 213-240.

Scott, Linda M. \& Batra, Rajeev (eds.) (2003). Persuasive imagery. A Consumer Perspective. Mahwah, NJ / London: Lawrence Erlbaum,

Shinohara, Kazuko \& Matsunaka, Yoshihiro (2009): Pictorial metaphors of emotion in Japanese comics. In C. Forceville \& E. Urios-Aparisi (eds.), 265-93.

Templin, Charlotte (1999): Hillary Clinton as Threat to Gender Norms: Cartoon Images of the First Lady. Journal of Communication Inquiry 23 (1): 20-36.

Teng, Norman Y. (2009): Image alignment in multimodal metaphor. In C. Forceville \& E. Urios-Aparisi (eds.), 197-211.

Urios-Aparisi, Eduardo (2009): Interaction of multimodal metaphor and metonymy in TV commercials: Four case studies. In C. Forceville \& E. Urios-Aparisi (eds.), 95-117.

Velasco-Sacristán, Marisol \& Fuertes-Olivera, Pedro (2004). Metáfora y LSP: valor cognitivo de la metáfora en el discurso publicitario de British Cosmopolitan. In I. Sanz and A. Felices (eds.), Las nuevas tendencias de las lenguas de especialidad en un contexto internacional y multicultural, 863-878. Granada: Universidad de Granada. 
Velasco-Sacristán, Marisol \& Fuertes-Olivera, Pedro (2006a): Towards a critical cognitive-pragmatic approach to gender metaphors in Advertising English. Journal of Pragmatics 38 (11): 1982-2002.

Velasco-Sacristán, Marisol \& Fuertes-Olivera, Pedro (2006b): Olfactory and olfactorymixed metaphors in print ads of perfumes. Annual Review of Cognitive Linguistics 4: 217-252.

Ventola, Eija; Cassily, Charles \& Kaltenbacher, Martin (2004). Perspectives on Multimodality. Amsterdam: John Benjamins.

Ventola, Eija \& Guijarro, Jesús (2009). The World Told and The World Shown: Multisemiotic Issues. Hampshire: Palgrave Macmillan.

Wiggin, Amy A. \& Miller, Christine M. (2003): 'Uncle Sam Wants You!' Exploring Verbal-Visual Juxtapositions in Television Advertising. In L.M. Scott \& R. Batra (eds.), 267-295.

White, Michael (2003): Metaphor and Economics: The case of growth. English for Specific Purposes: An International Journal of ESP 22/2: 131-151.

Yus, Francisco (2009): Visual metaphor versus verbal metaphor: A unified account. In C. Forceville and E. Urios-Aparisi (eds.), 147-172.

Zbikowski, Lawrence (2009): Music, Language, and Multimodal Metaphor. In C. Forceville \& E. Urios-Aparisi (eds.), 359-381.

Yu, Ning 2009: Nonverbal and multimodal manifestations of metaphors and metonymies: A case study. In C. Forceville and E. Urios-Aparisi (eds.), 119-143.

Received: January 28, 2013

Accepted: January 29, 2014

Revised: February 22, 2014

Published: February 24, 2014

Updated: March 3, 2014 